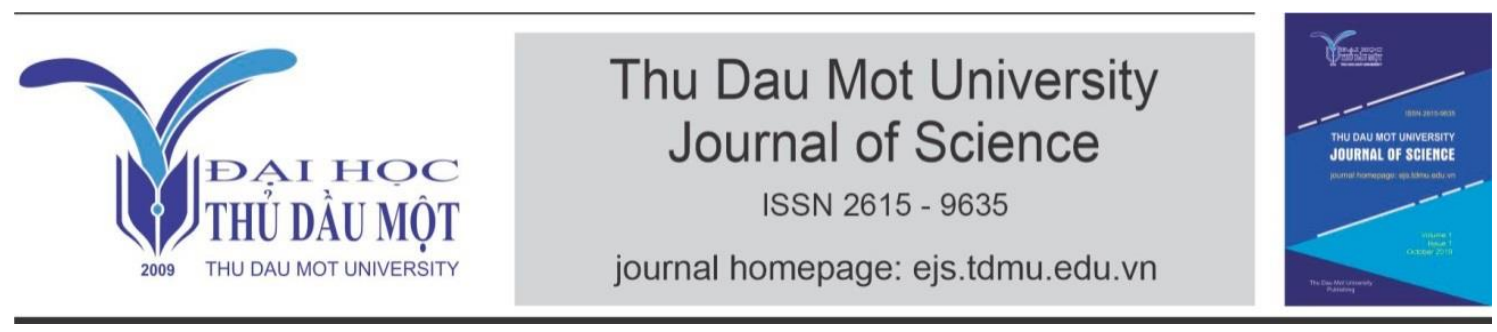

\title{
Evaluate the efficiency of the Environmental Management System Iso 14001:2015 at The Vietnam Onamba Company
}

by Nguyen Thi Xuan Hanh, Do Thi Kim Ty (Thu Dau Mot University)

Article Info: $\quad$ Received 15 Dec. 2019, Accepted 20 Mar. 2020, Available online 15 June. 2020 Corresponding author: nguyenthixuanhanh@gmail.com

https://doi.org/10.37550/tdmu.EJS/2020.02.044

\begin{abstract}
Nowadays, the benefits of ISO 14001:2015 abound, for minimizing environmental footprints, providing operational improvements, bringing lucrative business and improving the company's image. There is an annual audit to decide if the company's environmental management system meets the requirements of ISO 14001:2015. This is a significant audit that strongly affects the current certificate. The study to "Evaluate the efficiency of the environmental management system ISO 14001:2015 at the Vietnam Onamba Company" has been conducted to research the internal audit and examine any discordance in the environmental management system. The study carries out the internal audit of the environmental management system ISO 14001:2015 at VTO company by 3P method (P1: Paper check, P2: People interview, P3: Practice Observe). The result of the study showed a minor discordance at (6.2) Environmental Objectives and planning to achieve them. Regarding other clauses, they meet the requirements of the environmental management system. The result shows that the responsibility and careful observation of the company in controlling the system. The study evaluates reducing consumption (electricity, water, and chemicals) through collecting and comparing the data between 2017 and 2018. The results show the efficiency of reducing consumption: monthly electricity consumption reduced 21,86\% (377 MWh); monthly water usage reduced 17,89\% (1421 $\left.\mathrm{m}^{3}\right)$; annual chemical usage reduced from 3 to $6 \%$.
\end{abstract}

Keywords: discordance, environmental management system, ISO 14001 


\section{Introduction}

Vietnam Onamba Company (VTO) is funded by $100 \%$ investment from Japan, it is an affiliate of Onamba group in Vietnam. Its main products are wire harnesses and cables. The Onamba group is famous for its concern about the environment. The famous slogan is "Leave a beautiful planet as a legacy to future Generations". They also make efforts to continuously improve their environmental management system by establishing voluntary standards and business procedures to observe environmental laws and regulations as well as other requirements. VTO acquired an ISO 14001:2015 certificate for the first time in 2016.

The benefits of ISO 14001:2015 abound, for minimizing environmental footprints, providing operational improvements, bringing lucrative business and improving the company's image.

On 26th October 2016, VTO obtained an ISO 14001:2015 certificate for the first time, yet this certificate expired on 26/01/2019. Since 2019, VTO has been in the recertification period. On 25th January 2019, VTO obtained the new certificate. This current certificate is valid for three years (until 25/01/2022). However, there is an internal audit which happens every year to decide if the company has the right to use the certificate or not. The internal audit also indicates how the environmental management system affects the company.

That is the reason why the study "Evaluate the efficiency of the environmental management system ISO 14001:2015 at the Vietnam Onamba Company" has been conducted to research the internal audit and examine any discordance in the environmental management system. This study also evaluates reducing consumption (electricity, water, and chemical). Besides, the outcome of this research can be used as a reference for the internal audit of companies.

\section{Research methods}

\subsection{Data collection methods}

\subsubsection{Collect secondary data}

Collect the secondary data through journals, magazines, newspapers, books, online portals and other sources about environmental management system ISO 14001.

\subsubsection{Qualitative research}

Interview the managers and staff at the company by using questionnaires.

* Time of interview 
The interview starts from 7.30 am to 10.30 am on 20th September 2019.

The number of people in the interview

There are 20 people in the interview that included 10 mangers and 10 staffs.

There are one manager and one staff for an interview from each department.

* Places of the interview

The interview was hold at three areas at the Vietnam Onamba company:

a. Office area (includes 3 departments): (1) Accounting department; (2) Sales department; (3) Human resource department.

b. Factory office area (includes 5 departments): (1) Quality control department; (2) Purchasing department; (3) Logistics department; (4) Project department; (5) Production control department.

c. Factory area: (1) Technical department; (2) Production department

The content of the interview

Contents are related to the internal audit ISO 14001:2015.

\subsection{Data analysis}

Comparing and calculating the amount of water usage, electricity usage, and chemical usage through excel and charts.

\subsection{P method}

The 3P method is an effective and reliable method for internal audit. This method also supports the decision and manipulation of the manager to improve the organization.

The 3P method includes:

TABLE 1. The 3P method in internal audit

\begin{tabular}{|c|c|l|}
\hline Part & Name & \multicolumn{1}{c|}{ Specific content } \\
\hline P1 & Paper Check & Check the essential documents \\
\hline P2 & People Interview & $\begin{array}{l}\text { Interview the person who is in charge of the work and directly deal } \\
\text { with the procedures }\end{array}$ \\
\hline P3 & Practice Observe & $\begin{array}{l}\text { Observation makes the content in the procedures more apparent. } \\
\text { This activity ensures if the action is suitable with the requirements } \\
\text { or not }\end{array}$ \\
\hline
\end{tabular}

Source: InterConformity Assessment and Certification Company[2]

If each P meets the requirement, it will be considered as suitability. Otherwise, it will be considered as discordance. 
A discordance is considered as below:

Rapid discordance (M): The organization does not meet a compulsory requirement of the system.

$\Rightarrow$ With a rapid discordance $(\mathrm{M})$, the organization will have 10 days to correct it and the audit team will come back and audit again.

Minor discordance $(\mathrm{m})$ : The organization has a minor mistake in the requirements.

However, a few minor mistakes might equal to a rapid discordance.

$\Rightarrow$ With a minor discordance, the organization will correct itself within 90 days. Then, they have to provide the evidence to the audit team to get the certificate.

\section{* For instance:}

To audit the (6.2) Environmental Objectives and planning to achieve them, we follow the steps below: (P1) Paper Check: Check related documents and the company's environmental policy in 2019; (P2) People Interview: Interview managers and staff about the content of the company's environmental policy in 2019; (P3) Practice Observe: Observe and check the print of the company's environmental policy in 2019. Where can we see the environmental policy at the company?

\section{The outcome of the study}

\subsection{The outcome of the internal audit}

The study carries out the internal audit of the environmental management system ISO 14001:2015 at VTO company by 3P method (P1: Paper check, P2: People interview, P3: Practice Observe). The result of the study showed a minor discordance at (6.2) Environmental Objectives and planning to achieve them.

TABLE 2. The outcome of the internal audit

\begin{tabular}{|c|c|c|c|c|}
\hline No & $\begin{array}{c}\text { P1 } \\
\text { Paper } \\
\text { check }\end{array}$ & $\begin{array}{c}\text { P2 } \\
\text { People interview }\end{array}$ & $\begin{array}{c}\text { P3 } \\
\text { Practice } \\
\text { observe }\end{array}$ & Conclusion \\
\hline $\begin{array}{c}\text { (6.2) } \\
\text { Environmental } \\
\text { Objectives and } \\
\text { planning to } \\
\text { achieve them }\end{array}$ & Suitable & $\begin{array}{l}\mathrm{m} \\
\text { According to the result of the } \\
\text { interview, staff } \mathrm{T} \text { do not understand } \\
\text { the content of the environmental } \\
\text { objective in } 2019\end{array}$ & Suitable & $\begin{array}{c}\text { A minor } \\
\text { discordance }(\mathrm{m})\end{array}$ \\
\hline
\end{tabular}


The result of the study showed a minor discordance at (6.2) Environmental Objectives and planning to achieve them. Regarding other clauses, they meet the requirements of the environmental management system. This outcome shows the responsibility and careful observation of the company in controlling the system.

3.2. The efficiency of ISO 14001:2015 in reducing consumption (electricity, water, and chemicals)

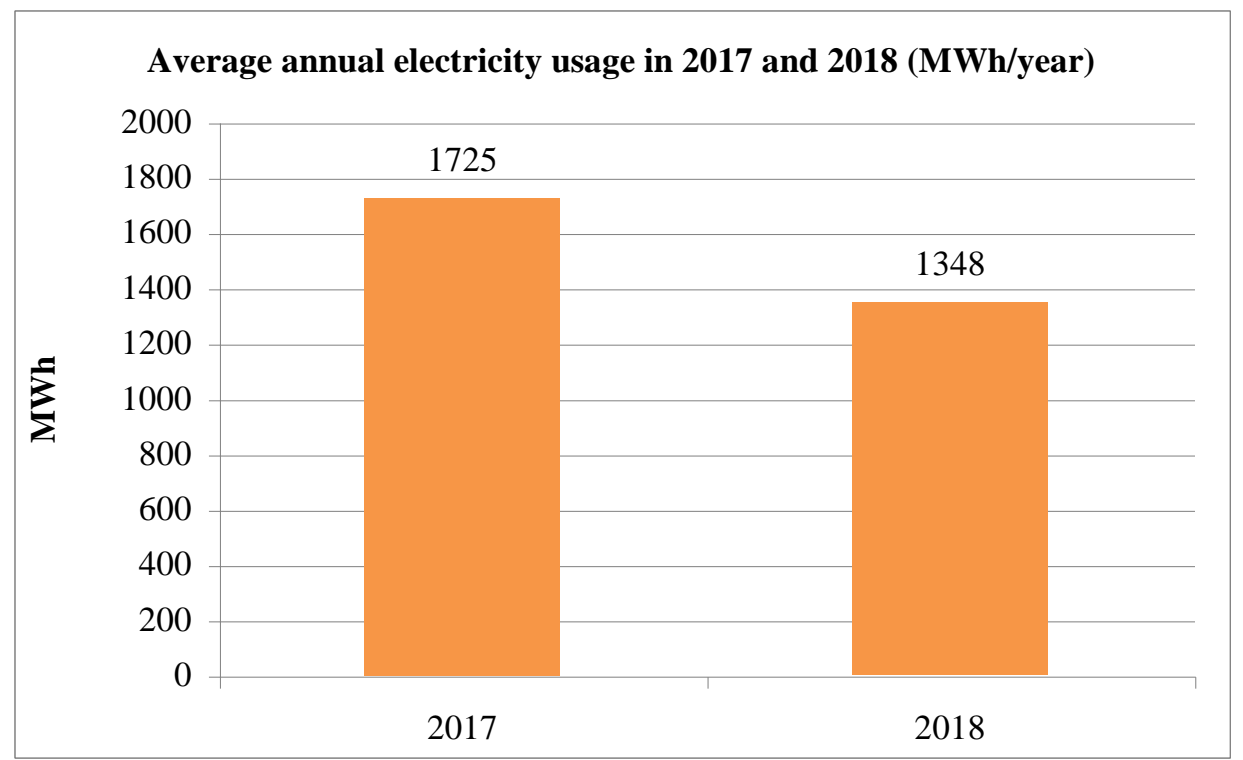

Source: Monthly report of the Vietnam Onamba company in 2017 and 2018

Figure 1. Average annual electricity usage in 2017 and 2018

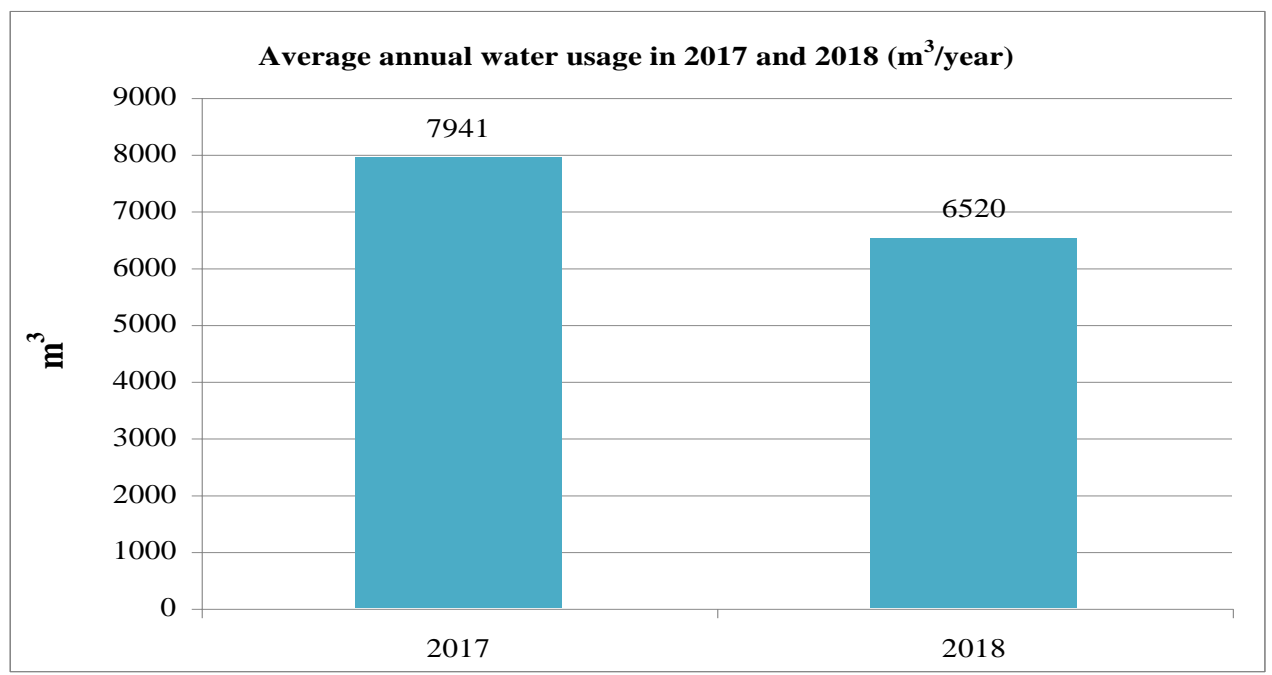

Source: Monthly report of the Vietnam Onamba company in 2017 and 2018

Figure 2. Average annual water usage in 2017 and 2018 


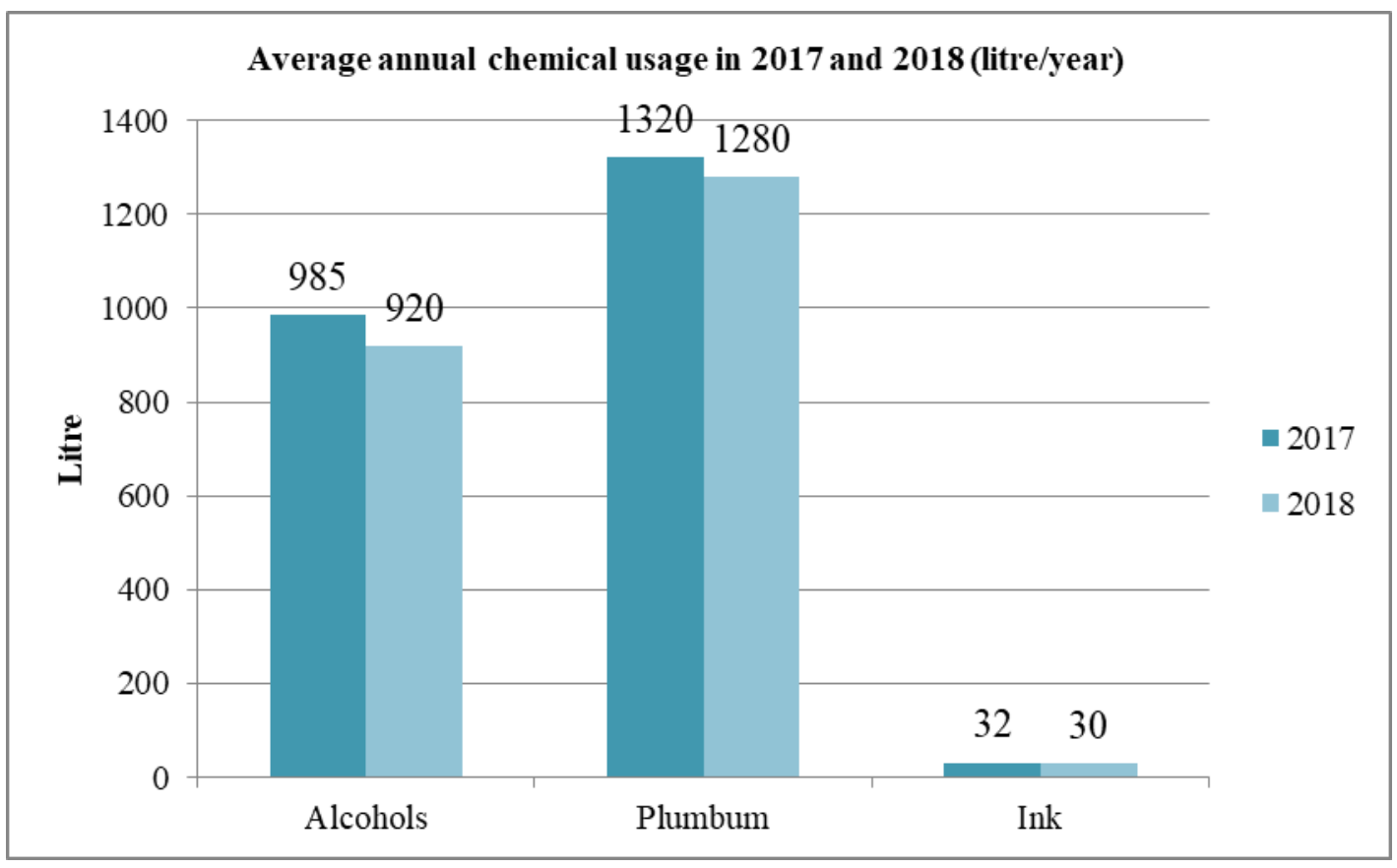

Source: Monthly report of the Vietnam Onamba company in 2017 and 2018

Figure 3. Average annual chemical usage in 2017 and 2018

The study evaluates reducing consumption (electricity, water, and chemicals) through collecting and comparing the data between 2017 and 2018. The results show the efficiency of reducing consumption: monthly electricity consumption reduced $21,86 \%$ (377 MWh); monthly water usage reduced $17,89 \%\left(1421 \mathrm{~m}^{3}\right)$; annual chemical usage reduced from 3 to $6 \%$.

\section{Conclusion and proposal}

The study carries out the internal audit of the environmental management system ISO 14001:2015 at VTO company by 3P method (P1: Paper check, P2: People interview, P3: Practice Observe). The result of the study showed a minor discordance at (6.2) Environmental Objectives and planning to achieve them. Regarding other clauses, they meet the requirements of the environmental management system. The result shows that the responsibility and careful observation of the company in controlling the system.

The study evaluates reducing consumption (electricity, water, and chemicals) through collecting and comparing the data between 2017 and 2018. The results show the efficiency of reducing consumption: monthly electricity consumption reduced $21,86 \%$ (377 MWh); monthly water usage reduced $17,89 \%\left(1421 \mathrm{~m}^{3}\right)$; annual chemical usage reduced from 3 to $6 \%$. In order to enhance the efficiency of ISO 14001:2015 at the Vietnam Onamba Company, we need to improve it by making changes in the management system. 
For instance, improving method of training staff and workers, the manager should explain the environmental objective clearly. Also, the manager should emphasize its meaning and how important it is with the company. Moreover, the company should encourage their staff in saving energy, water, and electricity at the company by following the procedures.

\section{References}

InterConformity Assessment and Certification Company. Internal documents. (2010)

ISO 14001:2015 Environmental manageent system - requirements with guidance for use, Ha Noi, 2010.

Vietnam Onamba Co., Ltd. Website: http://www.onamba.co.jp/?p=2371 